\title{
Peaches and Nectarines: Calendar of Operations for Home Gardeners
}

\author{
Pamela M. Geisel is UC Cooperative Extension Farm Advisor in Environmental Horticulture for \\ Fresno County; Carolyn L. Unruh is UCCE staff writer for Fresno County; and Paul Vossen is \\ UCCE Farm Advisor in Fruits, Vegetables, and Marketing for Sonoma and Marin Counties.
}

Peach and nectarine trees are now available in varieties that are well adapted to almost every climate zone in California. They require around 600 to 900 hours of chilling, though there are low-chill varieties available for southern California. Most are self-fruitful, but there are a few exceptions. They do best where they have good soil drainage and adequate irrigation in summer. Fruit thinning in spring and pruning in both winter and summer are critical because it is easy to overcrop an unthinned or unpruned tree.

\section{Winter Dormant Season}

1.If San Jose scale, mites, or aphids are recurring problems, spray trees with dormant oil late in the dormant season, just prior to bud break. Oil sprays applied late in the dormant season are least likely to cause shoot injury. Be sure to provide thorough coverage of the tree, including the trunk.

2.Spray to control peach leaf curl. Make two applications, the first around November 15 and the second about February 1. The latter should coincide with bud swell, but should occur before the buds show any color. Some effective materials are bordeaux, calcium polysulfide (lime-sulfur), and fixed copper.

3.Prune out any dead, diseased or broken branches. Prune off 50 percent of last year's wood to thin the crop and ensure good shoot growth and fruiting in future years. Early varieties are pruned more severely than later-maturing varieties, which can retain more fruit.

4. Remove and destroy all mummified fruit hanging on tree branches.

\section{Spring Bloom Season}

1.Begin to fertilize mature trees as they start to push out foliage in the spring. Use a high-nitrogen fertilizer such as ammonium sulfate at 3 to 4 pounds per tree per year. Use lower rates for very vigorous trees. Divide the total amount of fertilizer into two portions to be applied in spring and fall (April and early August).
2.In a year with prolonged spring rains, apply a fungicide during the bloom period to prevent brown rot or shot hole fungus. One application may be sufficient, or you may need to make two applications 14 days apart, depending on the weather. Apply the first spray when flowers show pink color but have not yet opened. Effective chemicals include bordeaux, fixed copper, and chlorothalonil.

3.Thin the fruit to about 6 inches apart when it is 1 inch in diameter. Prop up heavy limbs to prevent breakage. Remove and destroy all thinned fruit to reduce brown rot diseases.

4.In very hot regions, paint the trunks and lower branches of young trees with a 1:1 mixture of white interior latex paint and water to prevent sunburn injury and to reduce borer infestations. Apply the paint mixture from 2 inches below the soil line to 2 feet above. This generally is not a problem if trees receive adequate irrigation water during the growing season.

\section{Summer Growing Season}

1.If you use drip irrigation, apply just the amount of water needed to replace what is used by the tree and lost from the soil through evaporation. If you use sprinkler or flood irrigation, water about every two to three weeks, and provide enough water to wet the soil to a depth of 18 to 24 inches. Water requirements will vary depending on environmental conditions and your soil type.

2.Fertilize young or newly planted fruit trees with about $1 / 4$ pound of ammonium sulfate each month in the summer. Water the fertilizer in immediately to avoid nitrogen loss.

3.In late June or early July, remove the strong, vigorous shoots from the interior portion of the canopy to improve light penetration and air circulation in the tree's interior.

4.Harvest fruit as soon as it is firm ripe. Clean up fallen fruit immediately to minimize brown rot and infestations of dried fruit beetles. Store fully ripe fruit under refrigeration, or sun dry, can, or freeze it. 
Autumn

1.If shot hole fungus has been a problem in previous years, apply a fungicide in November before the first heavy fall rains. Use bordeaux or other fixed-copper chemicals. This application can be combined with the November spray to prevent leaf curl.

\section{For More Information}

Cousult these UC IPM Pest Notes online at http:/ / www.ipm.ucdavis.edu

Aphids
Bordeaux Mixture
Leaf Curl
Scales
Spider Mites
Thrips

You'll also find detailed information on many aspects of fruit and nut tree care in these titles and in other publications, slides sets, and videos from UC ANR:

California Master Gardener Handbook, publication 3382

Drip Irrigation in the Home Landscape, publication 21579

Pests of the Garden and Small Farm, publication 3332

Pruning Fruit and Nut Trees, publication 21171

Sweet Cherries for the Home Grounds, publication 2951

The UC Guide to Solving Garden and Landscape Problems, CD-ROM 3400

\section{ORDERING}

To order these products, visit our online catalog at http: / / anrcatalog.ucdavis.edu. You can also place orders by mail, phone, or fax, or request a printed catalog of publications, slide sets, and videos from

University of California

Agriculture and Natural Resources

Communication Services

6701 San Pablo Avenue, 2nd Floor

Oakland, California 94608-1239

Telephone: (800) 994-8849 or (510) 642-2431

FAX: (510) 643-5470

E-mail inquiries: danrcs@ucdavis.edu

For a free catalog of other publications, telephone (800) 994-8849.

Visit the ANR Communication Services website at http:/ / anrcatalog.ucdavis.edu.

\section{Publication 7261}

(C) 2002 by the Regents of the University of California, Division of Agriculture and Natural Resources. All rights reserved.

The University of California prohibits discrimination against or harassment of any person employed by or seeking employment with the University on the basis of race, color, national origin, religion, sex, physical or mental disability, medical condition (cancer-related or genetic characteristics), ancestry, marital status, age, sexual orientation, citizenship, or status as a covered veteran (special disabled veteran, Vietnam-era veteran or any other veteran who served on active duty during a war or in a campaign or expedition for which a campaign badge has been authorized).

University Policy is intended to be consistent with the provisions of applicable State and Federal laws. Inquiries regarding the University's nondiscrimination policies may be directed to the Affirmative Action/Staff Personnel Services Director, University of California, Agriculture and Natural Resources, 300 Lakeside Drive, 6thFloor, Oakland, CA 94612-3550; 510-987-0096. For information on how to obtain this publication and other ANR CS products, call 800-994-8849.

pr-1/02-JWC/CY

ISBN 978-1-60107-052-4

This publication has been anonymously peer reviewed for technical accuracy by University of California scientists and other qualified professionals. This review process was managed by the ANR Associate Editor for Pomology, Viticulture, and Subtropical Horticulture. 
WARNING ON THE USE OF CHEMICALS

Pesticides are poisonous. Always read and carefully follow all precautions and safety recommendations given on the container label. Store all chemicals in their original labeled containers in a locked cabinet or shed, away from foods or feeds, and out of the reach of children, unauthorized persons, pets, and livestock.

Confine pesticides to the property being treated. Avoid drift onto neighboring properties or gardens containing fruits and / or vegetables ready to be picked.

Dispose of empty containers carefully. Follow label instructions for disposal. Never reuse the containers. Make sure empty containers are not accessible to children or animals. Never dispose of containers where they may contaminate water supplies or natural waterways. Do not pour down sink or toilet. Consult your county agricultural commissioner for correct ways of disposing of excess pesticides. Never burn pesticide containers.

PHYTOTOXICITY: Certain chemicals may cause plant injury if used at the wrong stage of plant development or when temperatures are too high. Injury may also result from excessive amounts or the wrong formulation or from mixing incompatible materials. Inert ingredients, such as wetters, spreaders, emulsifiers, diluents, and solvents, can cause plant injury. Since formulations are often changed by manufacturers, it is possible that plant injury may occur, even though no injury was noted in previous seasons.

Funding for this publication was made possible through a grant from the Elvenia J. Slosson Fund. 